\title{
Strategi Peningkatan Kinerja Guru
}

\author{
Mohamad Muspawi \\ Prodi Administrasi Pendidikan FKIP Universitas Jambi \\ Correspondence email: muspawi01@gmail.com
}

\begin{abstract}
Abstrak. Kinerja guru adalah suatu kondisi yang menunjukkan kemampuan guru dalam menjalankan tugas dan tanggungjawabnya di sekolah selama melakukan aktivitas pembelajaran dan dapat memberikan dorongan serta pengaruh kepada peserta didik agar tujuan pembelajaran dapat tercapai dan berjalan dengan baik serta sesuai dengan yang diharapkan, yang ditunjukkan dalam penampilan, perbuatan, dan prestasi kerjanya. Kinerja guru ditentukan oleh empat faktor yaitu: (1) lingkungan; (2) karakteristik individu; (3) karakteristik organisasi; dan (4) karakteristik pekerjaan. Beberapa Upaya yang dapat dilakukan kepala sekolah untuk meningkatkan kinerja guru yaitu: 1) Membina kinerja guru, 2) Mengawasi kinerja guru, 3) Memberikan motivasi, 4) Mengevaluasi kinerja guru.
\end{abstract}

Kata kunci: Kinerja guru; Strategi Peningkatan

Abstract. Teacher performance is an effort and the ability of teachers to carry out their duties and responsibilities at school during learning activities and can provide encouragement and influence to students with the aim that learning objectives can be achieved and run well and as expected which is shown in appearance, actions, and his work performance. Teacher performance is determined by four factors, namely: (1) environment; (2) individual characteristics; (3) organizational characteristics; and (4) job characteristics. Some of the efforts that the principal can make to improve teacher performance are: (1) Teacher performance guidance, (2) Supervision of teacher performance, (3). Providing motivation, (4). Evaluating teacher performance.

Keywords: Teacher performance; improvement strategies

\section{PENDAHULUAN}

Guru merupakan figur sentral bagi pelaksanaan pendidikan di sekolah, sebab guru memiliki peran, fungsi, dan kedudukan dalam menghantarkan keberhasilan suatu pendidikan. Ketiadaan guru, tentu tidak ada yang mendidik anak-anak agar menjadi generasi muda yang berpendidikan. Selain itu, guru merupakan pihak yang selalu berhubungan dengan siswa secara langsung sehingga ia memiliki kesempatan lebih banyak untuk mendidik siswa agar menjadi generasi muda yang berpendidikan, bermoral baik, serta mencintai budaya Indonesia.

Kinerja guru merupakan gambaran tentang sikap, keterampilan, nilai, dan pengetahuan guru dalam melaksanakan tugas dan fungsinya, yang ditunjukkan dalam penampilan, perbuatan, dan prestasi kerjanya (Mulyasa, 2013). Kinerja guru adalah suatu kondisi yang menunjukkan kemampuan seorang guru dalam menjalankan tugasnya di sekolah serta menggambarkan adanya suatu perbuatan yang ditampilkan guru selama melakukan aktivitas pembelajaran (Supardi, 2013). Kinerja guru merupakan faktor atau kunci utama yang harus di miliki agar dapat mencapai tujuan pendidikan secara komprehensif, sebab itulah yang menjadi alasan pemerintah menyelenggarakan penilaian kinerja guru. Yamin \& Maisah (2010:87) mengatakan kinerja guru berkaitan dengan aktitivas menyeluruh guru dalam tanggung jawabnya sebagai seseorang yang mengemban amanah dan tanggung jawab dalam mengajar, mendidik, membina, dan mengembangan para peserta didik ke arah kesuksesan yang dituju.
Penelitian mengenai kinerja telah banyak dilakukan oleh para peneliti, antara lain Sarifudin (2019) tentang peningkatan kinerja guru dalam implementasi penilaian sistem SKS melalui supervisi akademik pengawas sekolah, Ramly (2017) tentang strategi peningkatan kinerja guru besar di perguruan tinggi negeri, Slameto, dkk (2017) tentang peningkatan kinerja guru melalui pelatihan beserta faktor penentunya, Emda (2016) tentang strategi peningkatan kinerja guru yang profesional, Nurmasyitah (2015) tentang implementasi manajemen stratejik dalam meningkatkan kinerja guru pada sekolah menengah kejuruan negeri 3 Lhokseumawe.

Kinerja guru dapat dipengaruhi oleh berbagai faktor. Adakalanya faktor tersebut bisa berasal dari diri sendiri berupa masih rendahnya motivasi kerja, pengetahuan, dan wawasan. Dapat pula berasal dari diri berupa rekan kerja, pimpinan, dan lingkungan di sekitar tempat kerja. Biasanya guru dapat terpengaruh oleh semangat kerja rekan kerjanya, lingkungan kerja yang nyaman juga akan sangat berpengaruh terhadap semangat kerja guru, lingkungan kerja yang kotor dan tidak menarik juga akan berpengaruh terhadap semangat kerja. Kemimpinan kepala sekolah juga sangat berpengaruh terhadap kinerja guru, karena kepala sekolah merupakan orang yang mengatur, mempengaruhi, dan memberikan motivasi terhadap kinerja guru. Oleh karenanya kinerja guru yang baik tidak terlepas dari peran strategis kepala sekolah selaku pemimpin tertinggi di sekolah, kepala sekolah harus dapat menuntun guru, memberikan motivasi, mengenal 
lebih dekat, menciptakan suasana kerja yang lebih nyaman untuk mencapai tujuan sesuai dengan visi dan misi yang telah ditetapkan.

\section{METODE}

Metode yang digunakan dalam penelitian ini adalah metode Library Research yakni penelitian kepustakaan, sebagaimana pendapat Nazir (2011) bahwa Studi kepustakaan adalah teknik pengumpulan data dengan mengadakan studi penelaahan terhadap bukubuku, literatur- literatur, catatan- catatan, dan laporanlaporan yang ada hubungannya dengan masalah yang dipecahkan. Dalam hal ini penulis memperdalam, mengkaji, dan menelaah literatur- literatur yang berkaitan dengan manajemen peserta didik, kemudian penulis lakukan analisis mendalam, dan selanjutnya disusun dalam bentuk artikel ilmiah.

\section{HASIL DAN PEMBAHASAN \\ Defenisi Kinerja Guru}

Supardi (2013) mengemukakan definisi kinerja sebagai hasil kerja yang telah dicapai oleh seseorang dalam suatu organisasi untuk mencapai tujuan berdasarkan atas standarisasi atau ukuran dan waktu yang disesuaikan dengan jenis pekerjaannya yang sesuai dengan norma dan etika yang telah diterapkan. Kinerja berasal dari kata performance. kata performance memberikan tiga arti, yaitu: (1) berarti prestasi, seperti dalam konteks atau kalimat "high performance car" atau " mobil yang sangat cepat"; (2) berarti pertunjukan, seperti dalam konteks atau kalimat "folk dance performance", atau "pertujukan tari-tarian rakyat"; (3) berarti pelaksanaan tugas, seperti dalam konteks atau kalimat "in performing his/her duities"(Ruky, 2002).

Kinerja memiliki makna yang cukup luas, karena berkaitan dengan perilaku individu dalam melaksanakan pekerjaannya. Kinerja merupakan suatu bentuk unjuk kerja seseorang yang ditunjukkan dalam penampilan, perbuatan dan prestasi kerjanya sebagai akumulasi dari pengetahuan, keterampilan, nilai dan sikap yang telah dimilikinya (Mulyasa, 2013). Kinerja adalah tentang apa yang dikerjakan, bagaimana cara mengerjakan dan hasil yang dicapai dari pekerjaan tersebut (Wibowo, 2007).

Berdasarkan pendapat tersebut, maka disimpulkan bahwa kinerja merupakan suatu bentuk hasil kerja dengan apa yang telah dikerjakan yang ditunjukan melalui penampilan, perbuatan dan prestasi kerja berdasarkan pengetahuan, keterampilan, nilai dan sikap yang dimiliki oleh individu.

Menurut Supardi (2013) kinerja guru adalah suatu kondisi yang menunjukkan kemampuan seorang guru dalam menjalankan tugasnya di sekolah serta menggambarkan adanya suatu perbuatan yang ditampilkan guru selama melakukan aktivitas pembelajaran. Sejalan dengan Supardi, Kompri (2015) mengartikan kinerja guru sebagai suatu kondisi yang menunjukkan kemampuan seorang guru dalam melaksanakan tugasnya di sekolah dan menggambarkan adanya suatu perbuatan yang ditampilkan guru dalam atau selama melakukan aktivitas pembelajaran.

Kempa (2015) mengatakan kinerja guru adalah keseluruhan perilaku guru dalam mencapai tujuan dalam pelaksanaan tugas yang dibebankan kepadanya baik sebagai pengajar, pelatih, pembimbing, pembinaan dan pendidik siswa, sehingga dari penguasaan tugas pokok tersebut dapat meningkatkan profesi guru dalam mengajar. Abbas (2017) kinerja guru pada dasamya lebih terarah pada perilaku seorang pendidik dalam pekerjaannya dan efektivitas pendidik dalam menjalankan tugas dan tanggung jawabnya yang dapat memberikan pengaruh kepada peserta didik kepada tujuan yang diinginkan.

Berdasarkan beberapa pendapat tersebut, dapat disimpulkan bahwa kinerja guru adalah suatu kondisi yang menunjukkan kemampuan guru dalam menjalankan tugas dan tanggungjawabnya di sekolah selama melakukan aktivitas pembelajaran dan dapat memberikan dorongan serta pengaruh kepada peserta didik agar tujuan pembelajaran dapat tercapai dan berjalan dengan baik serta sesuai dengan yang diharapkan, yang ditunjukkan dalam penampilan, perbuatan, dan prestasi kerjanya.

\section{Indikator Kinerja Guru}

Supardi (2013) menjelaskan bahwa indikator kinerja guru meliputi: pengetahuan, keterampilan, sistem penempatan dan unit variasi pengalaman, kemampuan praktis, kualifikasi, hasil pekerjaan dan pengembangan. Sardiman (2011) menyebutkan bahwa sehubungan dengan beberapa fungsi yang dimiliki guru maka terdapat beberapa aspek utama yang merupakan kecakapan serta pengetahuan dasar bagi guru yaitu: 1) Guru harus dapat memahami dan menempatkan kedewasaannya. Sebagai pendidik harus mampu menjadikan dirinya sebagai teladan dimana guru harus mampu memberi contoh perilaku yang baik, terbuka, serta menghindari segala perbuatan tercela dan tingkah laku yang dapat menjatuhkan martabat pendidik. 2) Guru harus mengenal diri siswanya. 3) Guru harus memiliki kecakapan memberikan bimbingan. 4) Guru harus memiliki dasar pengetahuan yang luas tentang tujuan pendidikan di Indonesia pada umumnya sesuai dengan tahap-tahap pembangunan. 5) Guru harus memiliki pengetahuan yang bulat dan baru mengenai ilmu yang diajarkan.

Mulyasa (2013) mengemukakan 8 keterampilan dasar mengajar yang harus dikuasai guru yaitu: (1) Keterampilan bertanya, (2) Keterampilan memberi penguatan, (3) Keterampilan mengadakan variasi, (4) Keterampilan menjelaskan, (5) Keterampilan membuka dan menutup pelajaran, (6) Membimbing diskusi kelompok kecil, (7) Keterampilan mengelola kelas, (8) Mengajar kelompok kecil dan perorangan. Winataputra (2003) Menyatakan bahwa pengelolaan kelas adalah 
serangkaian kegiatan guru yang ditujukan untuk mendorong munculnya tingkah laku siswa yang diharapkan dan menghilangkan tingkah laku siswa yang tidak diharapkan, menciptakan hubungan interpersonal yang baik dan iklim sosoi-emosional yang positif, serta menciptakan dan memelihara organisasi kelas yang produktif dan efektif. Pengelolaan kelas ditekankan pada aspek pengaturan (management) lingkungan pembelajaran yaitu berkaitan dengan pengaturan orang (siswa) dan barang/fasilitas. Kegiatan guru tersebut dapat berupa pengaturan kondisi dan fasilitas yang berada di dalam kelas yang diperlukan dalam proses pembelajaran diantaranya tempat duduk, perlengkapan dan bahan ajar, lingkungan kelas (cahaya, temperatur udara, ventilasi) dan lain-lain. Salah satu bentuk pengelolaan kelas adalah penataan tempat duduk, dimana penataan tempat duduk perlu memperhatikan lingkungan fisik kelas dan juga keanekaragaman karakteristik siswa, serta mempertimbangkan kesesuaian metode yang digunakan dengan tujuan akhir dari pembelajaran itu sendiri.

Aspek yang dinilai dalam menentukan kinerja seorang guru menurut Peraturan Menteri Pendayagunaan Aparatur Negara dan Reformasi Birokrasi No 16 tahun 2009, seorang guru mata pelajaran harus memiliki kemampuan : (1) menyusun kurikulum pembelajaran pada satuan pendidikan; (2) menyusun silabus pembelajaran; (3) menyusun rencana pelaksanaan pembelajaran; (4). melaksanakan kegiatan pembelajaran; (5) menyusun alat ukur/soal sesuai mata pelajaran; (6) menilai dan mengevaluasi proses dan hasil belajar pada mata pelajaran yang diampunya; (7) menganalisis hasil penilaian pembelajaran; (8) melaksanakan pembelajaran/perbaikan dan pengayaan dengan memanfaatkan hasil penilaian dan evaluasi; (9) menjadi pengawas penilaian dan evaluasi terhadap proses dan hasil belajar tingkat sekolah dan nasional; (10) membimbing guru pemula dalam program induksi; (11) membimbing siswa dalam kegiatan ekstrakurikuler proses pembelajaran; (11) melaksanakan pengembangan diri; (12) melaksanakan publikasi ilmiah; dan (13) membuat karya inovatif.

Saud (2013) mengatakan bahwa kinerja guru dalam proses mengajar harus memiliki komptensi yang terdiri dari; merencanakan proses pembelajaran, melaksanakan dan memimpin atau mengelola proses belajar, dan menilai kemajuan proses belajar megajar. Penilaian kinerja guru tersebut secara garis besar dapat dikelompokkan menjadi enam bagian utama yaitu (1) merencanakan pembelajaran; (2) melaksanakan pembelajaran dan (3) melakukan evaluasi atau penilaian hasil pembelajaran, (4) membimbing kegiatan ekstrakurikuler dan (5) membimbing guru pemula dan (6) pengembangan diri. Usman (2007) mengatakan kinerja guru bisa diamati dari kemampuan guru dalam melaksanakan proses belajar mengajar yaitu menyiapkan rencana pembelajaran, mengatur program belajar mengajar, mengelola kelas, memakai media atau sumber belajar, pemahaman landasan kependidikan, pelaksanaan program Bimbingan dan Penyuluhan/ Bimbingan dan Konseling, pelaksanaan evaluasi pembelajaran dan pelaksanaan administrasi sekolah untuk kelancaran proses belajar mengajar.

Indikator penilaian kinerja guru seperti yang terdapat pada Peraturan Menteri Pemberdayaan Aparatur Negara Nomor 16 Tahun 2009 di atas, dapat dijabarkan sebagai berikut: (1) Kemampuan seseorang dalam mengkomunikasikan pengetahuan sangat bergantung pada penguasaan pengetahuan yang akan dikomunikasikannya itu, (2) Kemampuan guru dapat dilihat dari cara atau proses penyusunan program kegiatan pembelajaran yang dilakukan oleh guru, (3) Kemampuan guru dalam mengelola pembelajaran menjadi hal penting karena berkaitan langsung dengan aktivitas belajar siswa di kelas, (4) Kemampuan melakukan evaluasi/ penilaian pembelajaran.

Hasil pekerjaan guru dilihat dari hasil yang telah dicapai oleh siswa. Dalam konteks pembelajaran sistem evaluasi menjadi tolak ukur untuk manilai sejauh mana pemahaman siswa terhadap materi yang diajarkan, yang mana sistem evaluasi tidak hanya berbentuk tugas, ulangan melainkan guru-guru juga menilai siswa dari segi afektif, kongnitif dan psikomotorik. Oleh karena itu, seorang guru perlu melakukan evaluasi terhadap belajar siswa untuk mengetahui sejauh mana tingkat kemampuan siswa tersebut dalam mengikuti proses kegiatan belajar di kelas. tapi bukan hanya siswa saja yang harus dievaluasi melainkan guru juga harus dievaluasi untuk mengetahui apakah sudah maksimal dalam menyampaikan pembelajaran kepada peserta didik atau sebaliknya. Mulyasa (2013) menyebutkan bahwa pada lembaga pendidikan, cara yang populer untuk pengembangan kemampuan profesional guru adalah dengan melakukan penataran (in service training) baik dalam rangka penyegaran (refreshing) maupun peningkatan kemampuan (up-grading). Cara lain baik dilakukan sendiri-sendiri (informal) atau bersama-sama, seperti: on the job training, workshop, seminar, diskusi panel, rapat-rapat, simposium, konferensi, dan sebagainya.

Saud (2013) menjelaskan bahwa pengembangan profesionalisme dan kompetensi guru, dapat dikembangkan melalui berbagai alternatif sebagai berikut: 1) Program peningkatan kualifikasi pendidikan guru. 2) Program penyetaraan dan sertifikasi. 3) Program pelatihan terintegrasi berbasis kompetensi. 4) Program supervisi pendidikan. 5) Program pemberdayaan MGMP (Musyawarah Guru Mata Pelajaran). 6) Simposium guru. 7) Program pelatihan tradisional lainnya. 8) Membaca dan menulis jurnal atau karya ilmiah. 9) Berpartisipasi dalam pertemuan ilmiah. 10) Melakukan penelitian (khususnya Penelitian Tindakan Kelas). 11) Magang. 12) Mengikuti berita aktual dari media pemberitaan. 13) 
Berpartisipasi dan aktif dalam organisasi profesi. 14) Menggalang kerjasama dengan teman sejawat.

Penilaian kinerja guru yang merujuk pada Peraturan Menteri Negara Pendayagunaan Aparatur Negara dan Reformasi Birokrasi Nomor 16 Tahun 2009 menyebutkan bahwa penilaian kinerja guru adalah penilaian dari tiap butir kegiatan tugas utama guru dalam rangka pembinaan karir, kepangkatan, dan jabatan. Penilaian kinerja guru sangat berkaitan dengan pelaksanaan tugas utama seorang guru dalam penguasaan pengetahuan, penerapan pengetahuan dan ketrampilan sebagaimana kompetensi yang dibutuhkan. Ambarita (2015) menjelaskan terdapat 10 kompetensi dasar yang harus dikuasai oleh seorang guru, antara lain; (1) Menguasai bahan/materi pelajaran; (2) Mengelola program pembelajaran; (3) Mengelola Kelas; (4) Menggunakan media dan sumber belajar; (5) Menguasai landasan pendidikan; (6) Mengelola Interaksi Pembelajaran; (7) Menilai prestasi belajar siswa; (8) Mengenal fungsi dan layanan bimbingan dan penyuluhan; (9) Mengenal dan menyelenggarakan administrasi sekolah dan; (10) Memahami dan menafsirkan basil penelitian guna keperluan pembelajaran.

Berdasarkan serangkaian uraian tersebut dapat disimpulkan indikator kinerja guru dalam mengajar terdiri atas: 1. Perencanaan pembelajaran, 2). Pelaksanaan pembelajaran, 3) Penilaian dan evaluasi hasil pembelajaran.

\section{Strategi Peningkatan Kinerja Guru}

Kepala sekolah sebagai figur yang bertanggung jawab terhadap lembaga pendidikan yang dipimpinnya hendaknya memiliki pandangan jauh ke depan bagi perkembangan dan kemajuan serta keberlangsungan sekolah. Muspawi (2020) menjelaskan bahwa kepala sekolah merupakan seorang guru yang diangkat dan ditugaskan secara formal menjadi pemimpin bagi sebuah sekolah untuk memberdayakan dan memimpin sumber daya sekolah dalam rangka meningkatkan mutu sekolah. Mengingat kepala sekolah yang setiap hari bertemu dengan para guru dan mengetahui secara langsung semua kegiatan dan proses dalam sekolah. Jadi paling tidak kepala sekolah mengetahui semua kekurangan dan kelebihan yang ada dalam sekolah. Untuk itu kepala sekolah sebagai pemimpin sekolah hendaknya mempertahankan dan mengembangkan kelebihan dan membenahi kekurangan-kekurangan yang ada dalam sekolah. Untuk itu peran kepemimpinan kepala seklah sangat urgen dalam sekolah, karena maju mundurnya sebuah sekolah tergantung kepada bagaimana kepemimpinan sekolah tersebut. Peran kepemimpinan kepala sekolah dalam sebuah lembaga pendidikan sangat banyak, diantaranya adalah kepemimpinan yang otokratis, lasissez faire, demokratis, dan teori-teori kepemimpinan, tipe-tipe kepemimpinan, fungsi kepemimpinan, pengertian kinerja, dan kriteria kinerja.
Kinerja merupakan kemampuan sesorang dalam usaha untuk mencapai hasil yang lebih baik ke arah pencapaian tujuan organisasi. Hal ini sesuai dengan visi misi yang ingin dicapai. Berbicara mengenai upaya kepala sekolah dalam meningkatkan kinerja guru tidak lepas dari tugas, fungsi dan tanggung jawab kepala sekolah itu menjalankan kepemimpinannya. Menurut Musbikin (2013) adapun upaya yang dapat dilakukan kepala sekolah untuk meningkatkan kinerja guru yaitu: 1) Pembinaan kinerja guru, 2) Pengawasan kinerja guru, 3) Pemberian motivasi, 4) Pengevaluasian kinerja guru.

\section{Membina Kinerja Guru}

Mengikutsertakan para guru dalam kegiatan seminar atau kepelatihan yang telah diprogramkan oleh pemerintah atau yang diadakan oleh sekolah. Melalui kegiatan seminar atau kepelatihan maka guru akan mendapatkan banyak pengetahuan dan guru dapat meningkatkan kinerjanya dalam kegiatan pembelajaran. Kepala sekolah melihat langsung kehadiran para guru dalam rangka pembinaan disiplin, kepala sekolah berusaha datang lebih awal untuk melihat kedatangan guru dan siswa tepat waktu atau tidak. Manfaat dari pembinaan kinerja guru yaitu: a. Memberikan pengetahuan dan ilmu untuk meningkatkan kinerja guru. b. Memberikan pedoman kepada guru-guru. c. Meningkatkan kesadaran kepada guru akan pentingnya kinerja guru yang baik untuk keberhasilan pendidikan.

Hal ini sejalan dengan hasil penelitian Busono (2016) yang melaporkan bahwa peningkatan kinerja seorang karyawan dapat dilakukan melalui pendidikan dan pelatihan. Metode 'on the job' merupakan metode yang paling banyak digunakan dalam pelatihan dan pengembangan. Karyawan dilatih tentang pekerjaan baru dengan supervisi langsung seorang pelatih yang berpengalaman (instruktur atau guru lain); Meliputi semua upaya bagi karyawan untuk mempelajari suatu pekerjaan sambil mengerjakannya di tempat kerja yang sesungguhnya. Berbagai macam metode yang digunakan adalah sebagai berikut: 1) Rotasi Jabatan (Job rotation), 2) Latihan Instruksi Pekerjaan (Job Instruction Learning), 3) Magang (Apprenticeship), 4) Coaching, 5) Penugasan sementara.

\section{Mengawasi Kinerja Guru}

Kepala sekolah dapat melakukan pengawasan dengan melakukan kunjungan kelas untuk melihat kinerja guru saat kegiatan pembelajaran. Dengan cara ini kepala sekolah dapat melihat dan menilai secara langsung bagaimana kinerja guru dalam melaksanakan tugasnya. Kepala sekolah dapat mengamati dan memahami sisi kelebihan dan kekurangan guru dalam mengajar, untuk kemudian sebagai bahan pengambilan kebijakan yang tepat. Pengawasan ditujukan tidak hanya terhadap tindakan guru ketika mengajar, tetapi juga meliputi berbagai hal dalam keseharian guru, termasuk 
mengenai sikap kepribadian, dan masalah perlengkapan mengajar.

\section{Memberikan motivasi}

Kepala sekolah memberikan motivasi untuk meningkatkan kinerja guru, pemberian motivasi dari kepala sekolah dapat berdampak positif terhadap kinerja guru karena motivasi merupakan salah satu cara untuk membangun semangat guru. Pemberian penghargaan dan memberikan hadiah merupakan suatu bentuk apresiasi yang diberikan terhadap guru yang berprestasi. Dengan memberikan penghargaan guru dapat termotivasi untuk lebih meningkatkan kinerjanya. Muspawi (2020) menginformasikan bahwa diantara hal yang dapat kepala sekolah lakukan untuk memotivasi guru adalah pertama memberikan reward dan punishment, mengajak guru untuk bekerja secara ikhlas, meningkatkan fasilitas kerja, serta menjaga kedekatan dengan para guru.

\section{Mengevaluasi Kinerja Guru}

Kegiatan mengevaluasi kinerja guru oleh kepala sekolah bertujuan untuk memperbaiki kinerja guru dalam kegiatan pembelajaran. Manfaat evaluasi kinerja guru: a. Untuk memahami secara faktual kinerja guru. b. Untuk meningkatkan kinerja guru. c. Untuk mengetahui keberhasilan kegiatan belajar. d. Untuk melakukan perbaikan kegiatan belajar.

Kepala sekolah bertanggung jawab mengarahkan apa yang baik bagi guru dan dia sendiri harus berbuat baik. Kepala sekolah juga harus menjadi contoh, bersikap sabar dan pengertian. Dengan demikian dapat dikatakan bahwa semakin baik peran dari seorang kepala sekolah maka akan dapat mengembangkan kinerja guru ke arah yang lebih baik, sehingga guru dapat menjadi tenaga pendidik yang profesional dalam peningkatan mutu pengajaran di sekolah.

\section{SIMPULAN}

Kinerja guru merupakan hal penting yang harus menjadi perhatian guru dan pihak terkait, guru harus memiliki kinerja yang baik, baik buruknya kinerja guru berpengaruh terhadap hasil belajar yang dicapai oleh siswa, sebab guru merupakan figur sentral dalam melayani pendidikan siswa di sekolah, dari guru ilmu pengetahuan mengalir ke diri siswa, dan dari kinerja guru pula kepribadian dan prestasi siswa terbentuk. Upaya yang dapat dilakukan kepala sekolah untuk meningkatkan kinerja guru yaitu: 1) Membina kinerja guru, 2) Mengawasi kinerja guru, 3) Memberikan motivasi, 4) Mengevaluasi kinerja guru.

\section{DAFTAR PUSTAKA}

Abbas, E. (2017). Magnet Kepemimpinan Kepala Madrasah Terhadap Kinerja Guru, Jakarta: Gramedia.

Ambarita. A. (2015). Kepemimpinan Kepala Sekolah. Yogyakarta: Graha Ilmu.
Busono, G. A. 2016. Pengaruh Sistem Pelatihan Dan Pengembangan Karyawan Terhadap Kinerja Karyawan PT. Persada Sawit Mas (PSM) Kecamatan Pampangan Kabupaten Ogan Komering Ilir. Muqtashid, 1(1), 81-114.

Emda. (2016). Strategi peningkatan kinerja guru yang profesional. Lantanida Journal, Vol. 4 No. 2, 2016: 111-117.

Kempa, R. (2015). Kepemimpinan Kepala Sekolah Studi Tentang Hubungan Perilaku Kepemimpinan, Keterampilan Manajerial, Manajemen Konflik, Daya Tahan Stres Dengan Kinerja Guru. Yogyakarta: Ombak

Kompri. (2017). Standarisasi Kompetensi Kepala Sekolah: Pendekatan Teori untuk Praktek Profesional. Jakarta: Kencana Prenada Media Group

Mulyasa. (2013). Uji Kompetensi dan Penilaian Kinerja Guru. Bandung: Remaja Rosdakarya.

Musbikin, I. (2013). Menjadi Kepala Sekolah Yang Hebat. Riau : Zanafa.

Muspawi, Mohamad. (2020). The Role Of Leaders In Increasing Motivation Teacher Work In Pondok Pesantren. Ta'dib: Jurnal Pendidikan Islam, Vol. 9 No. 1 (2020) 20-30. ISSN 1411-8173 | E-ISSN 2528-5092.

DOI: https://doi.org/10.29313/tjpi.v9i1.5932

Muspawi, Mohamad. (2020). Strategi Menjadi Kepala Sekolah Profesional. Jurnal Ilmiah Universitas Batanghari Jambi, 20 (2), Juli 2020, pp.402-409. DOI 10.33087/jiubj.v20i2.938. ISSN 1411-8939 (Online) | ISSN 2549-4236 (Print).

Nazir, M. Metode Penelitian, Jakarta, Ghalia Indonesia, cet.ke-5, 2011.

Nurmasyitah. (2015). Implementasi manajemen stratejik dalam meningkatkan kinerja guru pada sekolah menengah kejuruan negeri 3 Lhokseumawe. Jurnal Administrasi Pendidikan Pascasarjana Universitas Syiah Kuala, Volume 3, No. 2, Mei 2015: 158-168.

Peraturan Menteri Negara Pendayagunaan Aparatur Negara dan Reformasi Birokrasi Nomor 16 Tahun 2009 Tentang Jabatan Fungsional dan Angka Kreditnya.

Peraturan Menteri Pendidikan Nasional No 16 Tahun 2007 Tentang Standar Kualifikasi dan Kompetensi Guru. Jakarta: Depdiknas.

Peraturan Menteri Pendidikan Nasional Nomor 13 Tahun 2007 tentang Standar Kepala sekolah/madrasah.

Ramly. (2017). Strategi peningkatan kinerja guru besar di perguruan tinggi negeri. Jurnal Manajemen. Vol. 8, No. 2. Desember 2017, P: 136-150.

Ruky, A. S. (2002). Sistem Manajemen Kinerja. Jakarta: Gramedia Pustaka.

Sardiman. (2011). Interaksi dan Motivasi Belajar Mengajar. Jakarta: Rajawali Press. 
Sarifudin. (2019). Peningkatan kinerja guru dalam implementasi penilaian sistem SKS melalui supervisi akademik pengawas sekolah. Edukasi Islami: Jurnal Pendidikan Islam, VOL: 08/NO: 02 Agustus 2019. 417-343; DOI: 10.30868/ei.v8i2.539

Saud, Udin S. (2013). Pengembangan Profesi Guru, Bandung: Alfabeta.

Slameto, dkk. (2017). Peningkatan kinerja guru melalui pelatihan beserta faktor penentunya. Jurnal Pendidikan Ilmu Sosial, Vol 27, No.2, Desember 2017, p-ISSN: 1412-3835; e-ISSN: 2541-4569: $38-47$.

Supardi. (2013). Kinerja Guru. Jakarta: Rajawali Pers.

Usman, Manajemen Peningkatan kinerja Guru, Bandung, Mutiara Ilmu. 2007.

Wibowo. (2007). Manajemen Kinerja. Jakarta: Rajagrafindo Persada.

Winataputra, Udin S. (2003). Srategi Belajar mengajar. Jakarta: Universitas Terbuka Departemen Pendidikan Nasional.

Yamin, Martinis \& Maisah. (2010). Standarisasi Kinerja Guru. Jakarta: Gaung Persada. 